\title{
OPTMIZING THE PERFORMANCE OF PLOT SEEDER MACHINE TO SUIT WHEAT SEED PRODUCTION
}

\author{
Fouda T.* I. Salah El-Din **, A. Derbala***, \\ M. Darwesh ${ }^{* * *}$ and W. El-Kolaly
}

\section{ABSTRACT}

The plot seeders have a variety of distribution systems makes it possible to distribute the seed for a plot over multiple rows and many options allows you to customize the machine for many different applications. So when used a plot seeder to suitable for cultivation of wheat seeds must adjustment transmission mechanism and a feed cartridges diameter, as well as seeding shaft and distributor cone rotates. This study carried out to improve the performance of plot seeder and minimize the total damage during wheat seed production processes. The treatments under this study were at four diameters of feed cartridges (10, 15, 20 and $25 \mathrm{~mm} \emptyset)$, two kinds of distributor plat (distributor plat with and without partition)and three groups of sowing transmission. The variation coefficient of seeds and seeds damage were measured. The seeds damage generally increased with the decrease of feed cartridge from $15.6 \%$ at feed cartridge diameter $(10 \mathrm{~mm} \emptyset)$ to $2.4 \%$ at feed cartridge diameter $(25 \mathrm{~mm}$ $\emptyset)$. Also seeds damage increased with distributor plat with partition. That was $15.6 \%$ with distributor plat with partition and $14.6 \%$ without partition. The variation coefficient of seeds decreases at diameter of feed cartridge $(20 \mathrm{~mm} \emptyset)$ with distributor plat without partition and the first group of sowing transmission.

\section{INTRODUCTION}

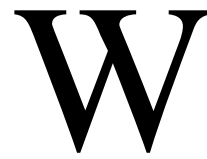

heat (Triticum spp L.) is one of the most important crops in Egypt and moreover is one of the world's first important cereal crops. The researchers plant some strategies to improve the production of wheat, by breeding new variety of seeds. It is important to conduct comparable tests in experimental plots with breeding, species, nutritional value and production research for wheat. The plot sowing operation is an important part of field experiments.

\footnotetext{
*Prof. of Agric. Eng. Dept. , Fac. of Ag., Tanta. Univ.

**Prof. of Agric. Eng. Res. Inst., Agric. Res. Center, Dokki, Egypt

**Assoc. Prof. of Agric. Eng. Dept., Fac. of Ag. , Tanta. Univ.

***Postgraduate of Agric. Eng. Dept., Fac. of Ag. , Tanta. Univ.
} 
Whether the sowing accuracy is good or not will directly affect the results of field experiments. Plot seeders are specially used for breeding new and good crop varieties in field experiments (Liu et al. 2010). Abu Shieshaa et al. (2007) mentioned that static coefficient of friction of seeds were $0.24,0.23$, and 0.34 for galvanized metal, stainless steel and plywood, respectively. Physical and mechanical properties for seeds considered are necessary to design the separating, hulling and handling equipment and other processing techniques. . Zoltán (2007) illustrated the working method of the belted cone distributor unit the seeds is fed into the supply cylinder and collected on the head of the distribution cone. When the operation of the plot starting supply cylinder is lifted, and the seeds are trickled down on the surface of the cone. Finally the seeds are driven into the groove, located between the base of the cone and the rubber conveyor belt. The seeds are moved by the rubber conveyor belt, driven by the cone. The cone with surrounding rubber belt must make one revolution depending on the length of the plot. The speed per revolution of the cone can be adjusted by changing the sprockets between the ground wheel and the driven cone. There is a hole on the circle surface of the cone, where the seeds can be flown out from the cone. Singh and Sarawat (2005) reported that the mean geometric diameter defined as ratio of the largest diameter inscribed circle over diameter of the largest circumscribed diameter of the seed. As well as, they added that the geometric mean diameter of the seed was calculated by the cube root of multiplying the thickness, length and width of seeds. Raheman and Singh (2005) developed a simple manual drawn drum seeder which can meter both wheat and mustard seeds. The field capacity of the seeder is $0.07 \mathrm{ha} / \mathrm{h}$ and $0.06 \mathrm{ha} / \mathrm{h}$ with a field efficiency of $83.5 \%$ and $78.4 \%$ for mustard and wheat, respectively. The average depth of seed placement, speed of operation and draft required for sowing mustard seed are $33 \mathrm{~mm}, 1.38 \mathrm{~km} / \mathrm{h}$ and $144 \mathrm{~N}$, respectively as compared to 47 $\mathrm{mm}, 1.24 \mathrm{~km} / \mathrm{h}$ and $176 \mathrm{~N}$ for sowing wheat. The main objective of this study is improving the performance of plot seeder through optimize the seed sowing transmission system and defined the relationship between rotating distributor plate and feeding cartridges. 


\section{MATERIALS AND METHODS}

The study was carried out at Sakha research center, Kafr El-Sheikh Governorate Egypt during 2014-2015 to investigate the performance and operating parameters of a seed plot system for sowing wheat seeds, a wheat seeds physical and mechanical properties were tested to determine the basic data more necessary for evaluate the influence of passing seed samples through feeding system of the seed plot system, and examine the seed viability before and after its passing.

\section{The physical and mechanical properties of wheat seeds.}

The physical and mechanical properties were measured using the following equations El-Raie et al. (1996).

$$
D_{g}=(D T L)^{\frac{1}{3}}
$$

Where: $\mathrm{D}_{\mathrm{g}}=$ mean geometric diameter of the seed $(\mathrm{mm}), \mathrm{L}=$ mean length $(\mathrm{mm}), \mathrm{W}=$ mean width $(\mathrm{mm})$, and $\mathrm{T}=$ mean thickness $(\mathrm{mm})$.

$$
\begin{aligned}
& D_{p}=\left[L \frac{(W+T)^{2}}{4}\right]^{\frac{1}{3}} \\
& \mathbf{D}_{\mathbf{a}}=\frac{(\mathrm{L}+\mathrm{W}+\mathrm{T})}{3} \\
& A_{f}=\frac{\pi}{4} L W \quad \mathrm{~mm}^{2} \\
& A_{t}=\frac{\pi}{4} \frac{(L+W+T)^{2}}{3} \quad \mathrm{~mm}^{2}
\end{aligned}
$$

A vernier caliper was used to determine length, width, and thickness of about 50 randomly selected grains of each sample. The mean geometric, $\mathrm{Dg}$, equivalent, $\mathrm{Dp}$ and arithmetic diameter, $\mathrm{Da}$, in $\mathrm{mm}$, transverse surface area, At, in $\mathrm{mm} 2$, flat surface area, Af, in $\mathrm{mm} 2$ was calculated by considering prelate spheroid shape for a wheat seeds. The sphericity (Sp) defined as the ratio of the surface area of the sphere having the same volume as that of grain to the surface area of grain, was determined using following formula of Mohsenin, (1986).

$$
\mathbf{S}_{\mathbf{p}}=\frac{(\mathrm{LDT})^{\frac{1}{3}}}{\mathrm{~L}}
$$

Coefficient of friction $(\mu)$ :- Coefficient of friction for each seeds sample under study was measured under the condition of three friction surfaces (rubber, galvanized and mild - steel).Coefficient of friction was calculated by instrument.

$$
\mu=\tan \theta
$$


Where: - Friction angle $(\theta)$ : Inclined angle of friction surface which caused start seeds slides on friction surface.

Repose angle seeds of (Ra):- The angle of repose of the wheat seeds was measured using the apparatus developed by Soliman (1994)

$$
\theta=\tan ^{-1}\left(\frac{2 \mathrm{H}}{D p}\right)
$$

Where: $\theta=$ dynamic angle of repose, degree. $\mathrm{H}=$ heap height, $\mathrm{cm}$ and $\mathrm{Dp}$ $=$ platform diameter, $\mathrm{cm}$.

Actual grains volume $(V)$ and real density $\left(\rho_{s}\right)$ :- The actual seeds volume was measured by using half-liter capacity graduated beaker. The graduated beaker was filled with water to a defined level, then (10 grams) of seeds were completely immersed in the beaker. The actual seeds volume was calculated $\left(\mathrm{cm}^{3} / \mathrm{g}\right)$ based on the difference between the two measured volumes of water for each 10 grams of seeds. Real density of seeds was calculated using the following equation:

$$
\rho s=\frac{M}{V} \mathrm{~kg} / \mathrm{m}^{3}
$$

Where:- $\rho_{\mathrm{s}}=$ The real density of seeds $\mathrm{kg} / \mathrm{m}^{3}, \mathrm{M}=$ Mass of seeds $(10 \mathrm{~g})$ and $\mathrm{V}=$ Actual volume of seeds $\mathrm{cm}^{3}$.

Seeds crashing force (CF):- Seed crashing force (in Newton) was determined for each seeds sample by using the crashing force instrument. All measurements were repeated 10 times, and then the mean value was calculated.

\section{Components of the plot seeder:}

The basic principle of the plot seeder is that all the openers are charged uniformly by a rotary distributor. This sowing system guarantees optimal distribution of the seeds within the row. Each plot is sown fully and without mixing in the non-stop mode. Openers for 6 rows can be used. The components of the plot seeder machine are shown in Fig. (1)

\section{Seed Flow Belted cone Distributor System:}

In this plot sowing system as shown in Fig. (2) The amount of seeds (which is previously weighted for each plot) is filled into the funnel (A), which is lifted manually by an operating person or automatically with electrical control by pressing the cycle key start which is actuated during the drive over the marker for plot beginning. 


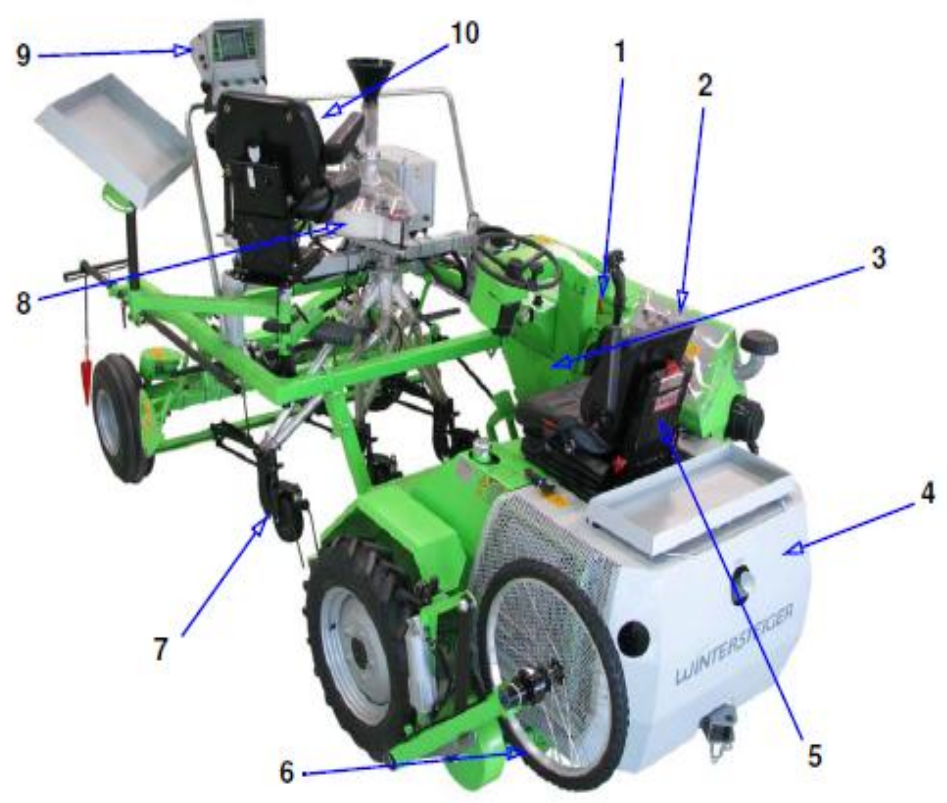

Fig.(1): Plot Seeder Components.

1. Sowing gear - 2. Operating panel - 3. Intermediate gearbox - 4. Motor 5. Driver's seat - 6. Measuring wheel - 7. Opener - 8. Distributor system 9. Sowing control unit PDS-E - 10. Workplace

The seeds are fed to the belted cone distributor $(\mathrm{C})$ via the delivery cone (B). This leads to optimum distribution of the seeds over the entire diameter. The belted cone distributor (C) effects exactly one rotation during the drive over the plot and during this time the seeds fall from the wedge between the band and the delivery cone via the funnel (D) and nozzle disc (E) (exchangeable) into the center on a rotating distributor (F). The rotating distributor $(F)$ is closed in by a distributor housing $(G)$, and it distributes the seeds very evenly into the corresponding outlets (rows).From the outlets the seeds are fed to the sowing shares (I) via the feed pipe $(\mathrm{H})$ and planted in the soil. Sowing of each plot takes place completely and hence absolutely free of mixtures.

\section{The feed cartridge for the rotary distributor}

The feed cartridges for the rotary distributor must be changed, depending on the seed type and seed volume. 


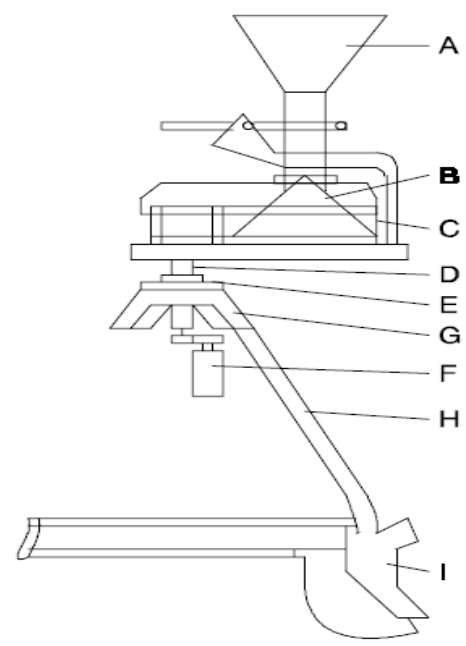

\section{Fig. 2 ): The Seed Flow Belted Cone Distributor System}

A- Funnel, B- cone, C- belted cone distributor, D- funnel, E- nozzle disc, Frotating distributor, G- distributor housing, H- feed pipe I- sowing shares.

Cartridges with large inner diameters for coarser seeds and large seed volumes, and small inner diameters for fine seeds and small seed volumes. Fig.(3) shown the Feed cartridges that made from still and available in the sizes $10,15,20$ and $25 \mathrm{~mm} \varnothing$.

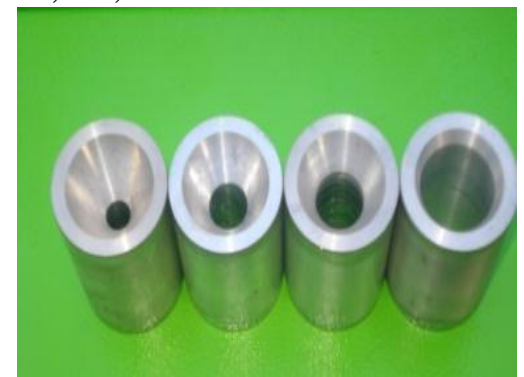

Fig. (3): The feed cartridge sizes 10, 15, 20 and $25 \mathrm{~mm} \emptyset$.

\section{The distribution plate}

The direction of rotation of the rotating distributor is a prerequisite for good distribution. Distribution must be turning clockwise. If direction of rotation is wrong, this will cause a bad distribution of the seeds and to mixtures. The distributor plate use to distribute seeds that come from feed cartridge and from the outlets the seeds are fed to the sowing shares via the feed pipe. Fig.(4) shown the distributor plate. 


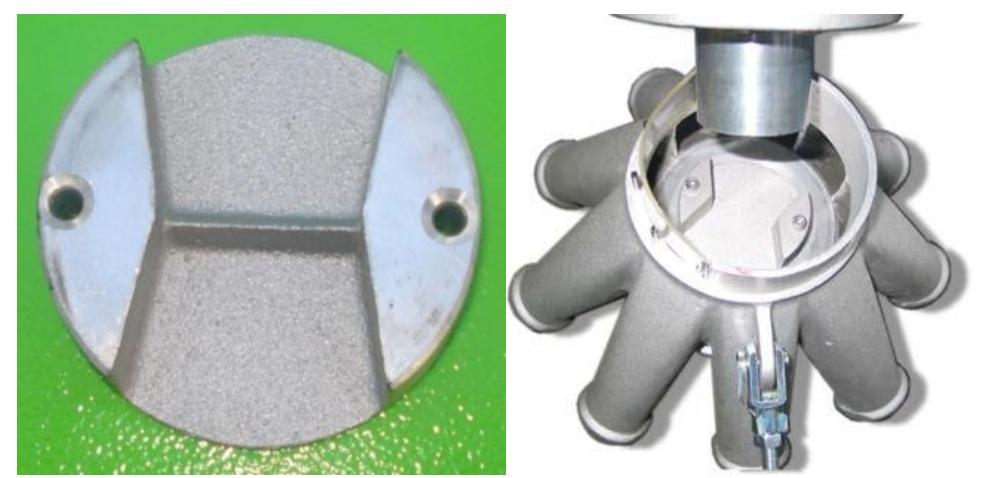

Fig.(4) shown the distributor plat with partition and without partition.

\section{The Sowing Transmission (G):}

The sowing transmission is driven depending on the soil conditions and serves to adjust various lengths of plots and seed distances. Adjustment and use of various chain wheels of the sowing drive depends on the plot lengths or grain distances for single grain sowing system nonstop.

The first group (G1): Sprocket with 29 teeth transmits motion from the engine to sprocket [R2] with 15 teeth that linked on sprocket with 30 teeth it's transmits motion to sprocket [R1] with 30 teeth that transmit the motion to the gearbox. In this group the sprockets transmit the same speed from the engine to the gearbox.

The second group (G2): Sprocket with 29 teeth transmits motion from the engine to sprocket [R4] with 15 teeth that linked on sprocket with 15 teeth it's transmits motion to sprocket [R3] with 20 teeth that transmit the motion to the gearbox. In this group the sprockets decrease the speed that came from the engine by (1/3).

The third group (G3): Sprocket with 29 teeth transmits motion from the engine to sprocket [R6] with 15 teeth that linked on sprocket with 25 teeth it's transmits motion to sprocket [R5] with 20 teeth that transmit the motion to the gearbox. In this group the sprockets decrease the speed that came from the engine by $(1 / 2)$.

\section{Experimental Procedures:}

The feed cartridges used in the investigation (F): (F1) $10 \mathrm{~mm} \varnothing,(\mathrm{F} 2)$ $15 \mathrm{~mm} \varnothing$, (F3) $20 \mathrm{~mm} \varnothing$ and (F4) $25 \mathrm{~mm}$ Ø. 
The distributor plat used in the investigation (P): (P1) distributor plat with partition and (P2) distributor plat without partition.

Sowing transmission used in the investigation (G): (G1) The first group, (G2) The second group, (G3) The third group

\section{Measuring the performance of the seed variation coefficient}

This is an indicator which used for making an optimum distribution of the seeds in plots by using the equation of variation coefficient of seeding uniformity $c v$ is followed as:

$$
C V=\frac{100}{\bar{x}} \sqrt{\frac{\sum_{i=1}^{n}\left(x_{i}-\bar{x}\right)^{2}}{n-1}}
$$

where: $x_{i}-$ The average amount of collected seeds at a certain test place during three measurements. $\mathrm{x}^{-}-$The average amount of collected seeds at all test places during three measurements. $\mathrm{n}$ - The number of test places.

\section{Seed damage and germination:}

\section{Percentage of visible seeds damage (external) (VD\%)}

Percentage of visible seeds damage was estimated through the following equation:-

$$
(\mathrm{VD} \%)=\left[\left(\mathrm{V}_{1}-\mathrm{V}_{2}\right) / 500\right] \times 100
$$

Where:- $\mathrm{V}_{1}=$ Number of damaged seeds in sample (500 seeds), which randomly segregated from every seeds sample after its passing through plot seeder feeding system. $V_{2}=$ Number of damaged seeds before passing seeds sample (500 seeds) through plot seeder feeding system.

\section{Percentage of invisible seeds damage (internal) (ID\%)}

Germination test was carried out to determine the invisible damage of seeds. A randomized sample of (100 seeds) visible unharmed seeds were taken and planted in Petri dishes to determine the germination percentage. The results were recorded after ten days from planting, and the germination percentage was estimated through the following equation:-

$$
(\text { ID\% })=\left[\left(\mathbf{N}_{2}-\mathbf{N}_{1}\right) / \mathbf{N}_{2}\right] \times 100
$$

Where: $-\mathrm{N}_{1}=$ Number of growing seeds.

$\mathrm{N}_{2}=$ Number of planting seeds (100 seeds). 


\section{The total seeds damage (TD\%)}

The percentage of total seeds damage (TD\%) were estimated basing on the following equation:

\section{TD $\%=$ VD $\%+$ ID $\%$ \\ RESULTS AND DISCUSSION}

The obtained results of this study can be discussed under two main heads. The physical and mechanical properties of wheat seeds.

The changed in seeds physical characteristics were investigated as the fundamental base for the plot seeder mechanism suitable for planting wheat seeds. The investigation included grain moisture content (MC), , shape index, weight of 1000 seeds (g), Flat surface area (Af) $\mathrm{mm}^{2}$, Transverse surface area (At) $\mathrm{mm}^{2}$, Geometrical mean diameter $\left(\mathrm{D}_{\mathrm{g}}\right) \mathrm{mm}$, Sphericity $\left(\mathrm{S}_{\mathrm{p}}\right) \%$, Arithmetic diameter, $\left(\mathrm{D}_{\mathrm{a}}\right) \mathrm{mm}$ and Seed density $\left(\rho_{\mathrm{s}}\right)$. The obtained results are summarized in Table (1).

Table. 1 Some physical properties of wheat seeds.

\begin{tabular}{|c|c|c|c|}
\hline \multicolumn{4}{|c|}{ Physical properties } \\
\hline$\left(\mathbf{D}_{\mathrm{g}}\right) \mathbf{m m}$ & 3.62 & $\left(\mathbf{S}_{\mathbf{p}}\right) \%$ & 61.46 \\
\hline$\left(A_{f}\right) \mathbf{m m}^{2}$ & 14.85 & $\left(\rho_{\mathrm{s}}\right) \mathrm{kg} / \mathrm{m}^{3}$ & 828.2 \\
\hline (At) $\mathrm{mm}^{2}$ & 6.33 & 1000 seed mass (g) & 39 \\
\hline$\left(D_{a}\right) \mathbf{m m}$ & 3.87 & $\%$ (M.C.) & 9.89 \\
\hline
\end{tabular}

Weight and Volume of 1000 Seed, Bulk density:

Weight and volume of one thousand seeds are major considerations in designing filling pipes, cone distributor and the feed cartridges. Estimating the mass of seed is necessary to assess the required mass of seed for planting a limited area and number of seed in each plot. Bulk density is major considerations in designing the sowing systems. Bulk density is also considered for determination of feed cartridges, designing seed filling pipes dimensions in plot seeder. The wheat weight, volume and bulk density of 1000 seeds were $39 \mathrm{~g}, 24.85 \mathrm{~mm}^{3}$ and $828.2 \mathrm{~kg} / \mathrm{m}^{3}$ respectively.

\section{The 3- Major dimensions:}

An average of ten replicates the 3-major dimensions of wheat seeds are 6.3, 3.5 and $3 \mathrm{~mm}$ shown Fig.(5). These differences in the 3-major dimensions gave an indicator that there will be big differences in the 
other measured physical characteristics, dimensions are important to design the feed cartridges, distributor plat and the sowing transmission. Main dimensions of seeds are considered in selecting, designing the suitable size of the feed cartridges and determination the proper method for sowing and separating: The highest value in each of the Length, width and thickness of the seed were $(6.3,3.5$ and $3 \mathrm{~mm})$ respectively. The highest frequency for the length of the seed $(30 \%)$ at $(5.8 \mathrm{~mm})$ and for the width $(36.67 \%)$ at $(3.1 \mathrm{~mm})$ and for the thickness was $(40 \%)$ at $(2.6$ $\mathrm{mm}$ ). Angle of Repose and Static Coefficient of Friction:

Angle of repose and coefficient of friction are important in designing equipment for distributor housing and rotating distributor. The coefficient of friction between seed and wall is an important parameter in the prediction of seed pressure on walls. Dynamic angle of repose for wheat is $28.52^{\circ}$. Coefficient of friction is the tangent of dynamic angle of repose. The static coefficient of friction for wheat of the investigated seeds type on the selected materials surfaces including rubber, galvanized and mild - steel as shown in Table (2).

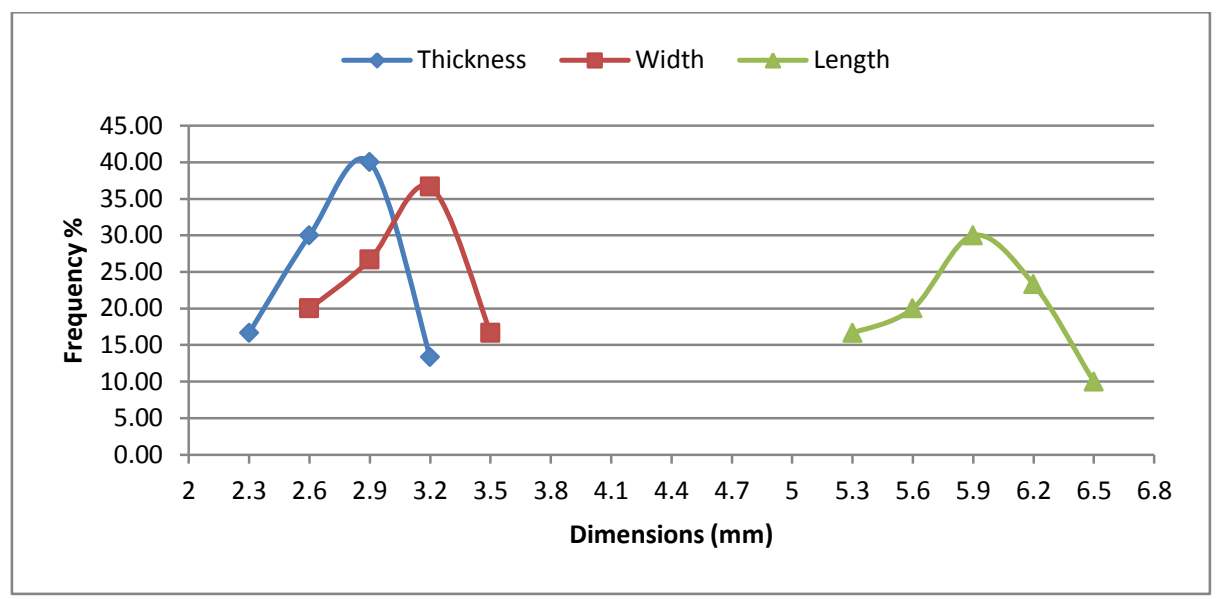

Fig (5): The 3-Major dimensions of wheat seeds (mm).

It is recommended to use this material in the structure of seed feed cartridges in plot seeder and rotating distributor plate.

\section{Visible and invisible damage}

The visible, invisible and total wheat damage data were calculated as the mean values of three measurements replicates 


\section{Visible seeds damage (VD)}

The visible, invisible and total wheat damage data were calculated as the mean values of three measurements and illustrated in figures (6 and 7) the wheat visible damage. The mentioned data indicated the highest value of visible seeds damage $15.6 \%$ was gained at feed cartridge diameter $(\varnothing$ $10 \mathrm{~mm}$ ) for first group of sowing transmission and distributor plat with partition, but this value was $2.4 \%$ by using feed cartridge diameter $(\varnothing 25$ $\mathrm{mm}$ )for first group of sowing transmission.

Table (2): Angle of repose and coefficient of friction and hardness.

\begin{tabular}{|l|l|}
\hline \multicolumn{2}{|c|}{ Mechanical properties } \\
\hline - Friction angle $\boldsymbol{\Psi}$ & 22 degree \\
For stainless surface & 34 degree \\
For metal surface & 40 degree \\
For rubber surface & \\
\hline - Coefficient of friction & \\
For stainless surface & 0.330 \\
For metal surface & 0.349 \\
For rubber surface & 0.384 \\
\hline Angle of repose & 28.52 \\
\hline Hardness & $4.135 \mathrm{~kg}$ \\
\hline Dynamic coefficient of friction $(\boldsymbol{\mu})$ & 0.54 \\
\hline
\end{tabular}

\section{Invisible seeds damage (ID)}

Data in figures (8 and 9) indicated that the feed cartridges diameters and sowing transmission groups and distributor plat were directly affected on invisible seeds damage. The highest value of invisible seeds damage was $20 \%$ was gained by using feed cartridge diameter $(\boldsymbol{\emptyset} \mathbf{1 0} \mathbf{~ m m})$ for first group of sowing transmission and distributor plat with partition, but this value was $2 \%$ by using feed cartridge diameter $(\varnothing \mathbf{2 5} \mathbf{~ m m})$ for first group of sowing transmission and distributor plat without partition.

\section{Total wheat seeds damage percentage (TD\%)}

Summation of visible and invisible seeds damage after passing through feeding systems of plot seeder was calculated as one measurement to express the total seeds damage (TD). The calculated values of (TD) which illustrated in figures (10 and 11) indicate the same trend to decrease total seeds damage by using the feed cartridges diameters and sowing transmission groups and distributor plat ( with partition and without 


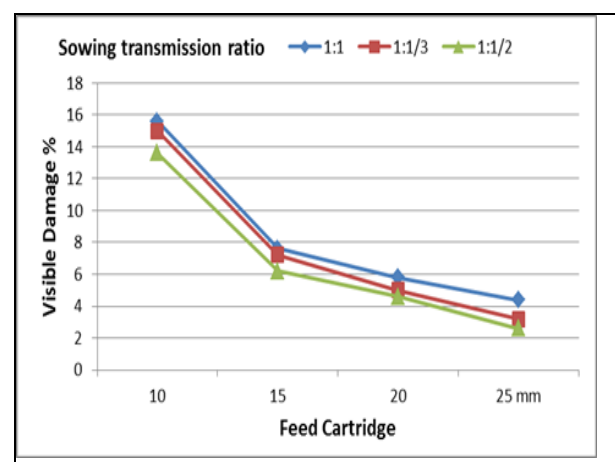

Figure (6): Effect of transmission groups and feed cartridges on visible damage of rotary distributor with partition

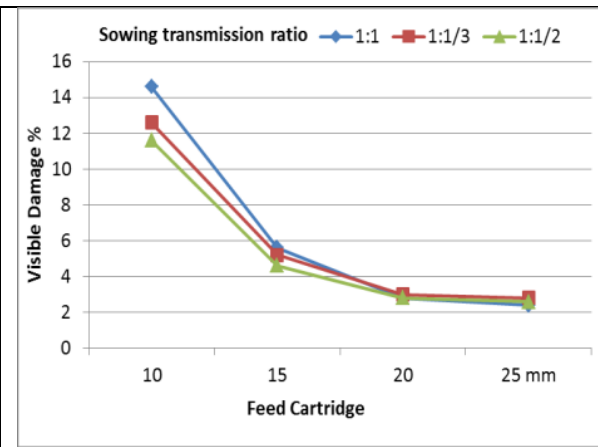

Figure(7): Effect of transmission groups and feed cartridges on visible damage of rotary distributor without partition

Sowing transmission ratio $\rightarrow-\infty: 1 \rightarrow-1: 1 / 3 \rightarrow 1: 1 / 2$

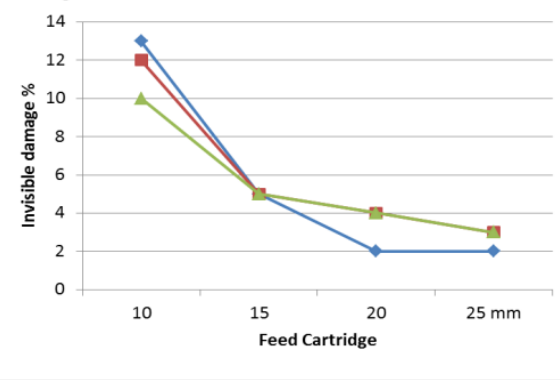

Figure (9): Effect of transmission groups and feed cartridges on invisible damage of rotary distributor without partition and feed cartridges on invisible damage of rotary distributor with partition
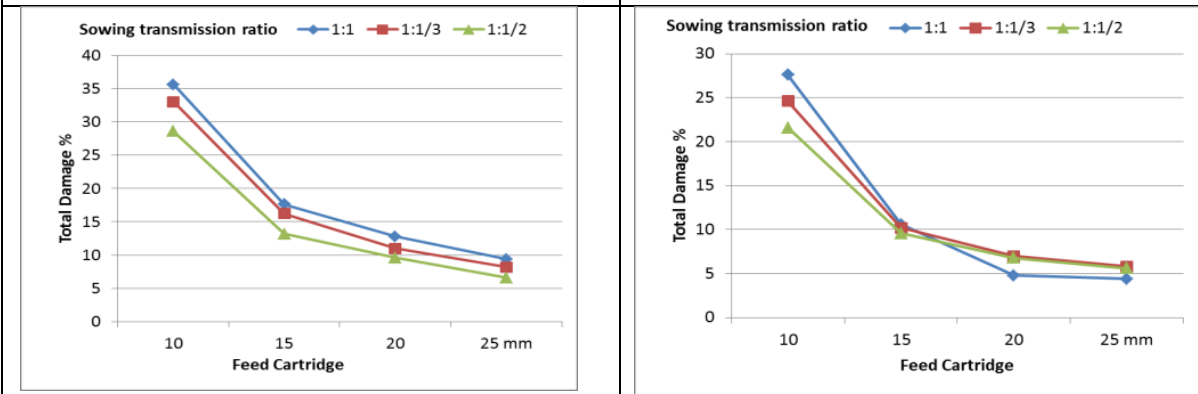

Figure (10): Effect of transmission
groups and feed cartridges on total
damage of rotary distributor with
partition.

Figure(11):Effect of sowing transmission groups and feed cartridges on Total damage of rotary distributor without partition. 
partition) at total damage $4.4 \%$, and also total seeds damage values, increased with small diameter of feed cartridge and first group of sowing transmission that's make more friction between seeds in the small cartage that make more damage between seeds that was $35.6 \%$

From the obtained data and previous explanation, this indicated high significant influence by using feed cartridge diameter $(\varnothing 25 \mathrm{~mm})$ for first group of sowing transmission and distributor plat without partition.

\section{The coefficient of variation (CV \%) for wheat seeds}

Inspection of data illustrated in figures from (12 and 13) shows the effect of the feed cartridges diameters and sowing transmission groups and distributor plats on coefficient of variation $(\mathrm{CV} \%)$ of wheat seeds. The recommended space between seeds in row $(2 \mathrm{~cm})$ each row needs 50 seeds / m. From data illustrated in figures (14 and 15) that the highest percentage of seeds variation was( 9.19 and $7.67 \%$ ) and the number of seeds in 2 meter was (29 and 100 seeds ) at first group of sowing transmission and feed cartridge diameter (10 and $25 \mathbf{~ m m ~ Ø ) ~ r e s p e c t i v e l y ~}$ and distributor plat with partition., but this was percentage of seeds variation was (6.85 and 6.08\%) and number of seeds in 2 meter was ( 45 and 100 seeds ) at first group of sowing transmission and feed cartridge diameter (15 and $20 \mathrm{~mm} \emptyset$ )respectively and distributor plat with partition. from this data the small feeding cartridge diameter and large one make high variation because the small one $(\varnothing \mathbf{1 0} \mathbf{~ m m})$ make seeds bass slowly throw the feeder but the beiger one $(\varnothing 25 \mathrm{~mm})$ make seeds bass faster and dropdown very narrow. Inspection of data tabulated in tables and figures the optimum value of the coefficient of variation was $(3.15 \%)$ which the number of seeds in 2 meter was 100 seeds and that is the recommended capacity of seeds per meter.

\section{CONCLUSION}

Laboratory measurements were carried out on wheat seeds to determined physical and mechanical properties, and the collecting data takes as a fundamental basic to introduce the most suitable engineering parameters for developed a plot sowing system of plot seeder suitable for planting wheat seeds. The developed plot sowing system of plot seeder had three engineering considerations to protect seeds against mechanical damage, there are:- 


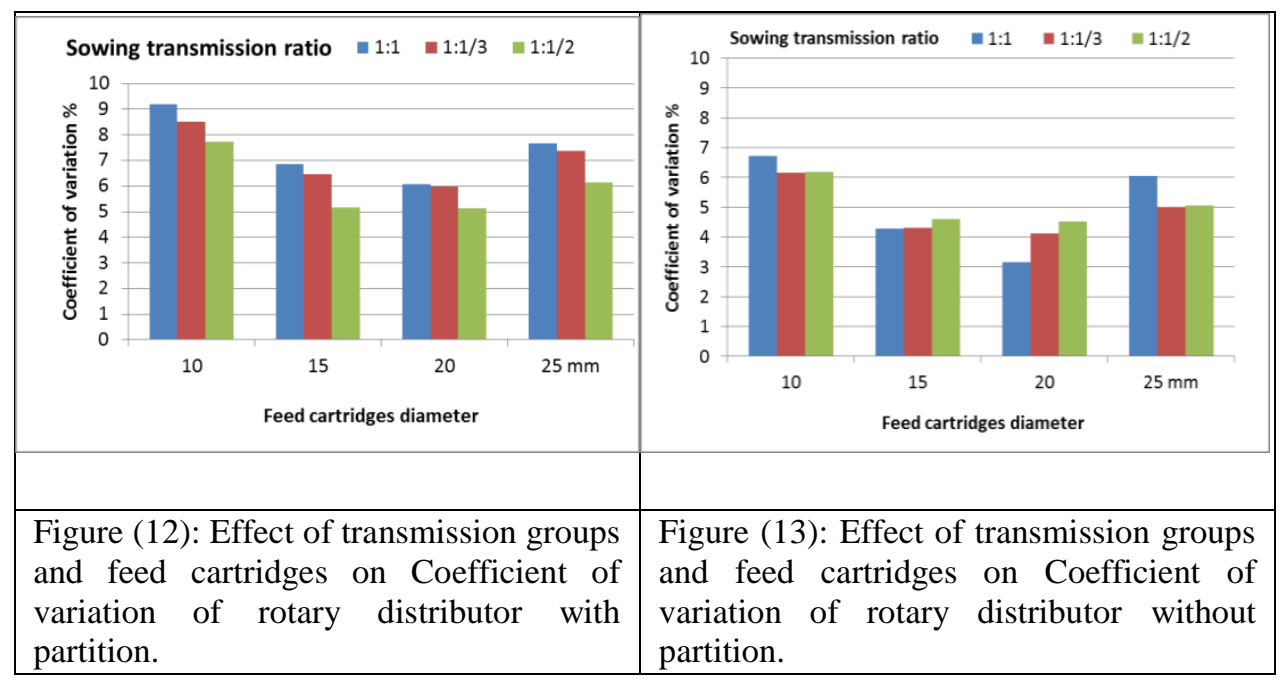

1- The feed cartridge of the sowing system had diameter $(20 \mathrm{~mm} \varnothing)$ to reduce the seeds damage.

2- The distributor plat of the sowing system was provided without partition to be cause the least seed crash.

3- Sowing transmission of the sowing system was the first group. In this group the sprockets transmit the same speed from the engine to the gearbox and that due to good distribute of seeds and given good seed variation.

\section{REFERENCES}

Abu - Shieshaa R., Kholief R., and EL - Meseery A. A., (2007), A study of some physical and mechanical properties of seed Melon seed, Misr J.Ag. Eng., 24(3):575 - 592.

El-Raie; A.E.S.; N. A. Hendawy and A.Z. Taib, (1996); Study of physical and engineering properties for some agricultural products. Misr. J. Ag. Eng., 13 (1) : 211-226.

Liu Shuguang, Shang Shuqi, Yang Ranbing (2010). Test and optimization of parameters for the storing device of plot seeder[J]. Transactions of the Chinese Society of Agricultural Engineering (Transactions of the CSAE), 2010, 26(9): 101 -107. 
Mohsenin, N. N., (1986); Physical Properties of Plant and Animal Materials, Gordon and Breach Sc. Pub., N. Y. pp. 734.

Raheman, H. and U. singh (2005): A manual Drawn multi-crop Drum seeder for dry land. Agricultural and food engineering department, Indian institute of tech : 58-63.

Singh, R. C and D. C. Saraswat (2005). Optimization of design and operational parameters of a pneumatic seed metering deice for planting cottonseeds. Bio-systems Engineering, 92(4): 429-433.

Soliman N.S.(1994). Effect of moisture content on angle of repose of Paddy rice and its products. Misr, J. Ag. Eng. 11(1):163-173.

Zoltán H. (2007). Examination of cone-belt dispenser $7^{\text {th }}$ international multidisciplinary conference Baia Mare, Romania, May 17-18, 2007 ISSN-1224-3264

\section{الملخص العربحي}

ضبط اداء الة زراعة البذور لتناسب انتاج تقاوى القمح

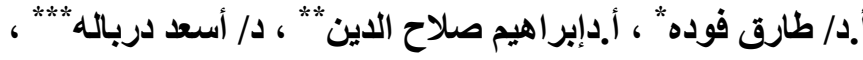

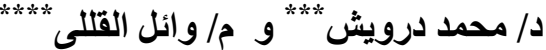

تعد عملية زر اعة بذور التقاوى من العمليات الهامة لاستنباط الاصناف الحديثه من التقاوى ـ و و

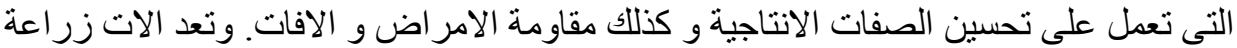

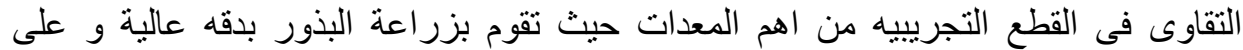
مساحات محدوده دون حدوث خلط بين الاصناف المنزر عه. ويهدف البحث الى تطوير وحدة وحدة

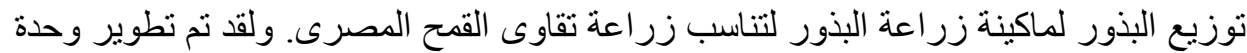

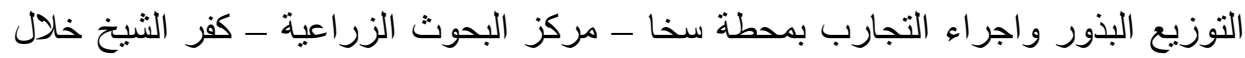

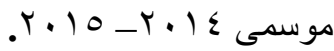

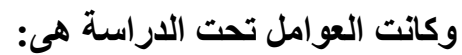

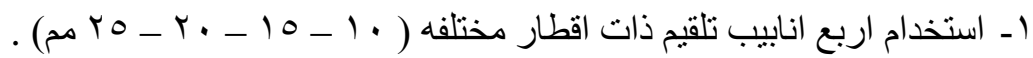

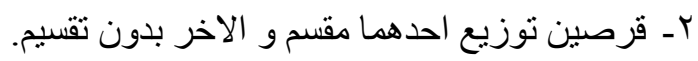

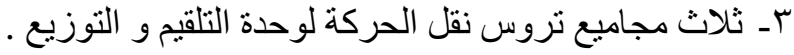

* أستاذ الهندسه الزراعيه ـ كلية الزراعه-جامعة طنطا. ** * * *تاذ الهندسه الزراعيه ـ معهد بحوث الهندسة الزراعية ـ مركز البحوث الزراعية ـ مصر.

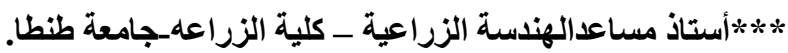

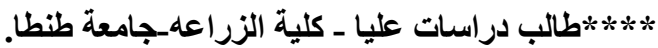




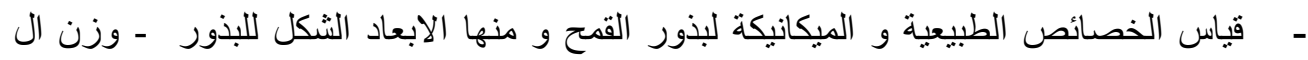

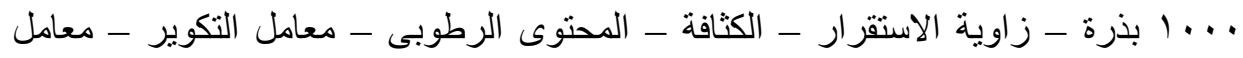

الاحتكاك - قوة سحق البذور. - - قياس نسبة التلف الغير مرئى للبذور.

- - قياس نسبة التلف الكلى للبذور. - - قياس كفاءة توزيع البذور داخل القطع التجريبية .

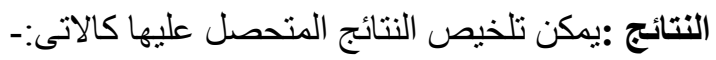

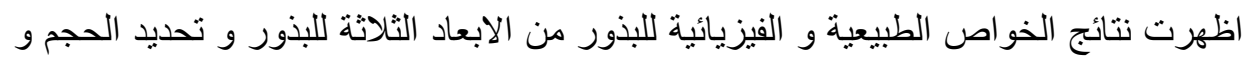

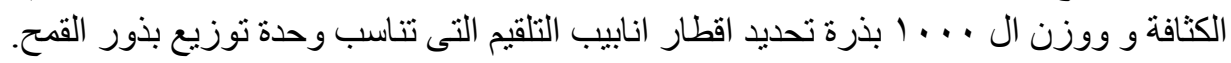

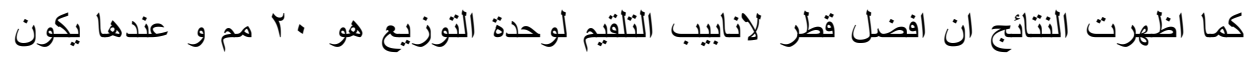

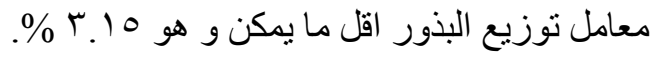

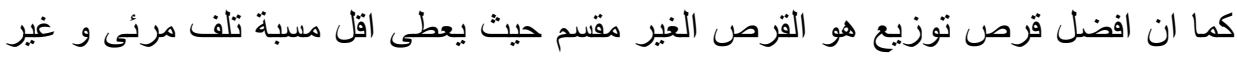

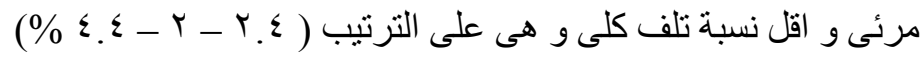
و افضل مجموعه تروس نقل الحركة هى المجمو عه الاولى و التى تعطى اقل معلى معامل توزيع

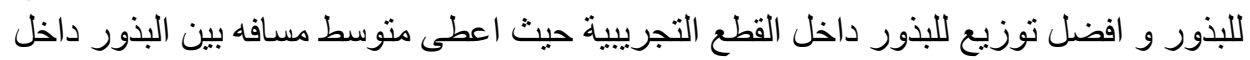

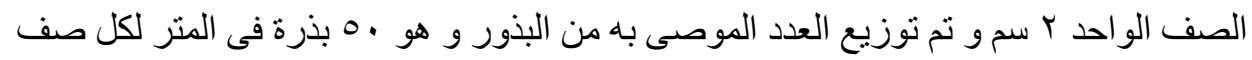

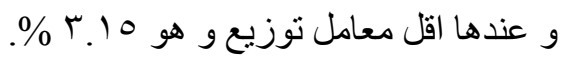

